\title{
Yaşlılarda Düşmeler ve İlişkili Risk Faktörlerinin Yaş ve Cinsiyete Göre Değerlendirilmesi
}

\section{Defining Falls and Associated Risk Factors in Elderly Among Age Groups and Sex}

Tahsin Gökhan Telatar ${ }^{1}$,

Sarp Üner²,

Hilal Özcebe ${ }^{3}$,

Burcu Küçük Biçer ${ }^{4}$

Özge Yavuz Sarı ${ }^{5}$,

${ }^{1}$ Recep Tayyip Erdoğan Üniversitesi Tıp Fakültesi Halk Sağlığı Anabilim Dalı, Rize, Türkiye

${ }^{2}$ Hacettepe Üniversitesi, Halk Sağlığı

Enstitüsü, Ankara, Türkiye

${ }^{3}$ Hacettepe Üniversitesi, Tıp Fakültesi, Halk Sağıı̆ı Anabilim Dalı, Ankara, Türkiye ${ }^{4}$ Yüksek Ihtisas Üniversitesi, Tıp Fakültesi, ${ }^{5}$ Etimesgut Toplum Sağlığı Merkezi, Ankara, Türkiye

Gelis Tarihi/Received: 25 Subat 2019 Kabul Tarihi/Accepted: 2 Temmuz 2019

Yazışma Adresi: Tahsin Gökhan Telatar, Recep Tayyip Erdoğan Üniversitesi, Tıp Fakültesi, Halk Sağlığı Anabilim Dalı, Rize, Türkiye

e-posta:gokhantelatar@gmail.com

\section{ORCID}

Tahsin Gökhan Telatar

https://orcid.org/0000-0002-3261-3464 Sarp Üner

https://orcid.org/0000-0002-9880-8811 Hilal Özcebe

https://orcid.org/0000-0002-0918-8519 Burcu Küçük Biçer

https://orcid.org/0000-0002-5615-264X Özge Yavuz Sarı

https://orcid.org/0000-0002-9762-6354

\begin{abstract}
Öz
Amaç: Araştırmada Türkiye, Sinop ilinde yaşayan yaşlıların düşme sıklıklarının ve düşmelerle ilişkili risk faktörlerinin belirlenmesi amaçlanmıştır.

Hastalar ve Yöntem: Kesitsel tipteki araştırmamızın evrenini 2013 yılında Sinop ilinde yaşayan ve aile hekimliği bilgi sistemine kayıtlı olan 32506 kişilik 65 yaş ve üzeri nüfus oluşturmaktadır. Cinsiyet ve yaş gruplarına (65-74, 75 ve üzeri) göre yapılan tabakalama sonucunda 2463 kişilik örnek büyüklüğü belirlenmis ve \%92,1'ine ulaşıımıştır. Yapılandırılmış bir anket formu aracılığıyla katılımcıların bazı sosyo-demografik özellikleri, düşme durumları, günlük yaşam aktivitelerindeki fonksiyonellikleri, depresyon durumları ve düşmeler konusundaki farkındalıklarını içeren veriler toplanmıştır. Risk faktörlerinin düşmelerle ilişkisi dört farklı lojistik regresyon modeli kullanılarak hesaplanmıştır.

Bulgular: Araştırmaya katılan yaşıların 65 yaşından sonra düşme prevalansları $\% 36,4$ olarak bulunmuştur. Herhangi bir okuldan mezun olmamış olmak, mevcut sağlık durumunu düşük puanlamış olmak, sürekli olarak ilaç kullanıyor olmak, günlük kullandığı ilaç sayısının fazla olması, desteksiz olarak yürüyememek ve depresyonda olmak her iki yaş grubu ve cinsiyet için de düşme riskini artıran faktörler olarak tanımlanmıştır. Herhangi bir kronik hastalığa sahip olmak, yalnız yaşamak, düşme korkusu yaşıyor olmak, düşmeler konusunda farkındalığın düşük olması, günlük yaşam aktivitelerinde bağımsız olmamak ve düşmelerden korunma hakkında yetersiz bilgi sahibi olmak yaş ve cinsiyet gruplarının en az ikisinde düşme riskini artıran faktörler olarak bulunmuştur. Daha önce gelir getiren bir işte çalışmış olmak ve halen çalışıyor olmak ile düşme riski arasında istatistiksel olarak anlamlı bir ilişki saptanamamıştır Sonuç: Düşmeler yaşlılık dönemi için önemli bir halk sağlığı sorunudur ve düşmelerin önlenmesi ile risk faktörlerinin kontrolü konularında ileriye dönük müdahalelerin planlanmasında 65 yaş üzeri nüfus içerisinde yaş ve cinsiyet gibi belirleyicilere bağlı olarak risk faktörlerinin değişiklik gösterdiği göz önüne
\end{abstract} alınmalıdır.

Anahtar Kelimeler: Yaşıılık, düşmeler, risk faktörleri, farkındalık, depresyon

\section{Abstract}

Aim: This study aims to determine the prevalence of falls and associated risk factors among elderly living in Sinop, Turkey.

Patients and Methods: The universe of this cross-sectional study consists of 32506 people older than 65 years old whom are registered to the family physicians' information system and live in Sinop. After stratification for sex and age (65-74, 75 and over) a sample size of 2463 and $92.1 \%$ were reached. Data about some of the socio-demographic characteristics, falling status, daily living activity functionalities, depression status and awareness about falls of the participants were collected via a structuralized questionnaire. Relations between falls and associated risk factors were assessed by four different logistic regression models.

Results: The mean of falling prevalence after age 65 among elderly was $36.4 \%$. Not being graduated from any school, having low scores for current health conditions, using more than one drug daily, not being able to walk without support and being positive for depression are found to be risk factors for falling among both sex and age groups. Having a chronic disease, living alone, having fear of falling, having low awareness about falls, being dependent in daily living activities and having inadequate knowledge about prevention from falls are found to be risk factors for at least two of the sex and age groups. There were no statistically significant relations between falling risk and previous or current employment status.

Conclusion: Falls are important public health concerns among elderly and the variability of risk factors depending on determinants such as age and sex should be considered while planning further implementations targeting fall prevention and control of risk factors for elderly.

Keywords: Elderly, falls, risk factors, awareness, depression

\section{GíRiş}

Dünya Sağlık Örgütünün yaşlı olarak belirlediği 65 yaş üzeri nüfus dünyada ve Türkiye'de giderek Atıf yapmak için: Telatar TG, Üner S, Özcebe H, Biçer BK, Sarı ÖY Yaşlılarda Düşmeler ve İlişkili Risk Faktörlerinin Yaş ve Cinsiyete Göre Değerlendirilmesi. Selcuk Med J 2020;36(2): 101-108 artmaktadır. Türkiye'de yaşlı nüfus son beş yılda $\% 17$ artarak 2017 yllında 6 milyon 895 bin 385 (toplam nüfusun $\left.\% 8,5^{\prime} \mathrm{i}\right)$ kişiye ulaşmıştır. Doğurganlıktaki 
düşüş ve doğumda beklenen yaşam süresinin uzaması sonucunda yaşlı nüfusun toplam nüfus içindeki payı giderek artmaktadır. Yaşlı nüfus oranın 2080 yılında \%25,6'ya ulaşacağı tahmin edilmektedir. Araştırmanın yapıldığı Sinop ili Türkiye'de 65 yaş üzeri nüfusun \%18.2 ile en yoğun olduğu il durumundadır(1). Bu durum yaşlıların karşılaştığı sorunlara verilmesi gereken önemin daha da artması gerekliliğini göstermektedir.

Yaşlılığın doğası gereği bireylerde meydana gelen değişiklikler sonucunda kişiler sağlık sorunları ve farklı risklerle karsı karşıya kalmaktadırlar. Düşmeler, yaşlılık dönemindeki en önemli yaralanma nedenlerinin başında gelmektedir(2). Toplum tabanlı epidemiyolojik çalışmalarda yaşılarda düşme sıklığı \%28-35 olarak saptanmıştır(3). Sıklığı bu denli yüksek olan düşmeler sonucunda yaşlılar yumuşak doku zedelenmeleri, kırıklar, uzun süreli hareketsizlik, kendine bakım yetisi kaybı gibi problemlerle karşı karşıya kalabilirler. Yaşlılarda düşmeler kalça kırıklarının \%95'ini oluşturmaktadır ve bu vakaların \%20'si ölümle sonuçlanmaktadır(4). Yaşlılarda düşmelerin fiziksel ve ruhsal olumsuz etkilerinin yanı sıra topluma mali yükleri de çok yüksek seviyelerdedir. 2004 yılında Kanada'da yaşılırın düşmelerinden kaynaklanan ekonomik yük 2 milyar dolar olarak hesaplanmıştır(5). Yaşlılarda düşmeye neden olabilen çeşitli hazırlayıcı faktörlerden önemli bir kısmı önlenebilir faktörler olduğundan, ilgili risk faktörlerinin saptanması, bunlara yönelik önlemler alınması ve yaşlıların ve beraber yaşadığı ya da bakımından sorumlu olan kişilerin bu önlemler yönünden farkındalıklarının arttırılması düşme sıklığının azaltılmasına katkı sağlayacaktır(6). Düşmelerin büyük çoğunluğu ciddi fiziksel yaralanmalara sebep olmasa da, ruhsal ve fonksiyonel sonuçları ciddi olabilmektedir(7). Düşme korkusu, anksiyete, kendine olan güvenin kaybolması ve aktivitelerden kaçınma davranışının gelişmesi sonucunda yaşlıların yaşam kalitesinde kayda değer azalmalar meydana gelmektedir(8). Yaşılırda düşmelerle ilgili farkındalığın ve bilgi düzeyinin artırılması, düşmelere bağlı korku gibi olumsuz ruhsal durumları ve düşme sıklığını azaltmaktadır(9). Yaşlılıkta görülen çeşitli hastalıklar ve durumlar göz önüne alındığında bile düşmeler tek başına yaşlılarda yaşam kalitesini azaltan önemli bir faktör durumundadır(10).

Bu çalışmada Sinop İlinde yaşayan yaşlıların bazı özelliklerinin belirlenmesi, bu özellikler ile yaşam kaliteleri, günlük bazı aktiviteleri, ruhsal durumları ile düşme sıklıkları arasındaki ilişkiyi saptamak; düşmeye bağlı oluşan sağlık sorunlarını ve düşmelerine sebep olan risk faktörlerini ve düşme konusundaki farkındalıklarını iki yaş grubu (65-74 ve 75 ve üzeri) ile cinsiyetlere göre belirlemek amaçlanmaktadır.

\section{HASTALAR VE YÖNTEM}

Kesitsel tipteki araştırmamızın evrenini 2013 yılında Sinop ilinde yaşayan ve aile hekimliği bilgi sistemine kayıtlı olan 32506 kişilik 65 yaş ve üzeri nüfus oluşturmaktadır. Cinsiyet ve yaş gruplarına (6574,75 ve üzeri) göre yapılan tabakalama sonucunda bilinen büyüklükte evren için örneklem büyüklüğü formülü kullanılarak örnek büyüklüğü hesaplanmıştır. Kullanılan formül şu şekildedir;

$\mathrm{n}=[\mathrm{N}(\mathrm{t} 1-\alpha) 2(\mathrm{p} . \mathrm{q})] /[\mathrm{S} 2(\mathrm{~N}-1)+((\mathrm{t} 1-\alpha) 2(\mathrm{p} . \mathrm{q})] \quad$ Burada $\mathrm{N}$ evrendeki kişi sayısını belirtmektedir ve bizim çalışmamız için 32506 'dır. " $n$ " örnekte en az bulunması gereken kişi sayısıdır ve 334 olarak hesaplanmıştır. "p" değeri yaşlılarda bilinen düşme prevelansıdır ve daha önce yapılan ulusal ve uluslararası çalışmalardaki yaşlılarda düşme prevelansları incelenerek, örneklem hesaplanmasında yaşlılarda düşme prevelansı \%34 olarak kullanılmıştır(11-17). "q" değeri araştırılan olayın toplumda görülmeme sıklığını yani (1-p) değerini işaret etmektedir. " $S$ " değeri elde edilecek hızın standart sapmasını göstermektedir ve 0,05 olarak belirlenmiştir. Son olarak (t1- $\alpha)$ değeri, belirli güven düzeyinde $t$ tablosundan bulunacak serbestlik derecesi değeridir ve 1,96'ya karşılık gelmektedir. "n" örnekte en az bulunması gereken kişi sayısıdır ve 342 olarak hesaplanmıştır. Desen etkisi 1,5 alınan çalışmada cinsiyet (2 grup) ve yaşa (2 grup) göre karşılaştırma yapılması amaçlandığından, \%20 olası cevapsızlıkta göz önüne alınarak örneklem büyüklüğü 2463 olarak belirlenmiştir.

Aile hekimlerinin kayıtlı nüfusları, 65 yaş üstü nüfuslarına orantılanmış ve kayıtlı gruplardan bu orantıya göre belirlenen sayıda yaşıının araştırmaya katılması planlanmıştır. Kişilerin seçilmesinde sistematik rastgele örnekleme yöntemi kullanılmıştır. Aile hekimliği sisteminde nüfusun tamamına yakını aile hekimine kayıtlı olduğundan seçilen örneklemin, evreni temsil ettiği düşünülmektedir. Örneklemde belirlenen 2463 kişiden ulaşılabilen ve yüz yüze görüşmeyi tamamlayabilmesine herhangi bir engeli bulunmayan 65 yaş ve üzeri 2269 (\%92,1) kişi çalışmaya katılmıştır. Araştırmaya katılanların cinsiyet ve yaş gruplarına göre dağılımı Tablo 1'de gösterilmektedir. Araştırmanın verileri, "Sinop İli 65 Yaş ve Üstü Bireylerin Yaşam Kaliteleri, Depresyon ve Düşme Sıklıklarının Değerlendirilmesi" adlı çalışmanın 
veri formlarından elde edilmiştir. Araştırmada kullanılan verilerin ilk bölümünü katılımcıların bazı sosyo-demografik özellikleri sağlık durumları ve sağlık hizmeti kullanımlarıyla düşme durumlarının değerlendirildiği bölümler oluşturmaktadır. Diğer bölümlerde kişilerin günlük yaşam aktivitelerindeki fonksiyonelliklerinin değerlendirildiği Lawton-Brody Enstrümental Günlük Yaşam Aktiviteleri İndeksi (LBI), yaşılıarda depresyon riskini değerlendiren Geriatrik Depresyon Ölçeği (GDÖ) ve yaşlıların düşme konusundaki farkındalıklarını değerlendiren Yaşlılar İçin Düşme Davranışları Ölçeği (Fab) yer almaktadır.

LBI fonksiyonelliği ölçmektedir; fonksiyonellik yaşlanma ile birlikte akut ve kronik hastalıklar, hastane bakımı gibi bazı durumlar sonucu günlük yaşam aktivitelerini yerine getirememeye bağlı olarak toplum içinde yaşamanın güçleşmesi olarak tanımlanmaktadır. Bu indeks değerlendirme sonucunda hedef grubun ihtiyacı olan rehabilitasyon hizmetleri ve birtakım evde bakım hizmetleri (yemek yapma, temizlik, faturalarını yatırma, finansal destek ve ilaçların kullanımı konusunda destek vb...) belirlenebilmektedir (18, 19). LBI; katılımcıların çeşitli günlük aktivitelerini değerlendiren sekiz sorudan oluşmaktadır. Katılımcı günlük aktivitelerini başkalarına bağımlı olmadan yapabiliyorsa 3 puan, çevresinden yardım alarak yapabiliyorsa 2 puan, günlük aktivitelerini gerçekleştiremiyorsa 1 puan verilerek değerlendirilmektedir. LBI puanı 0 ile 8 arasındaysa birey bağımlı, 9 ile 16 puan arasındaysa yarı bağımlı, 17 ve 24 puan arasındaysa bağımsız olarak kabul edilmektedir. Türkçe geçerlilik ve güvenilirliği olmayan ölçek Hacettepe Üniversitesi Tıp Fakültesi Geriatri Bilim Dalı'nda 65 yaş üstü hasta muayene formu olarak kullanılmaktadır ve Türkiye'de yaşlı sağıı̆ı ile ilgili bazı araştırmalarda kullanılmıştır (20-22).

Yaşlılarda depresyon riskini değerlendiren GDÖ, 1982 yılında Yesavage ve arkadaşları tarafından kullanıma sunulmuştur (23) ve Türk toplumu için geçerlilik ve güvenilirlik çalışması iki farklı çalışmayla değerlendirilmiş ve uygun bulunmuştur $(24,25)$.
Ölçek yaşlı bireyler için geliştirilmiştir ve 30 soru içermektedir. Yaşlıda depresyon belirtisi olarak kabul edilecek yanıtlar 1 puan, diğer yanıtlar 0 puan olarak değerlendirilmektedir. Ölçekten alınabilecek en yüksek puan 30'dur. GDÖ'den alınan puanların değerlendirilmesinde 0 ile 10 puan arası depresyon olmadığı, 11 ile 13 puan arası olası depresyon varlığı, 14 ve üzeri puan ise kesin depresyon olarak kabul edilmektedir. Araştırmamızda GDÖ analizinde puanlar 11 altı (depresyon riski yok) ve 11 ve üzeri (depresyon riski var) olarak gruplanmıştır.

Clemson, Cuming ve Heard tarafından 2003 yılında İngilizce olarak geliştirilen Fab ölçeğinin (26) geçerlik ve güvenirlik çalışması ülkemizde Uymaz ve Nahcivan tarafından yapılmıştır (27). Fab 30 madde ve 10 alt boyuttan oluşmaktadır (28). Hastaların Fab puan ortalamaları hesaplamasında en düşük puan ortalaması değeri ' 1 ' olup en yüksek puan ortalaması değeri 4'tür. Puan ortalaması yükseldikçe hastaların düşme konusundaki farkındalıkları artmaktadır. Veriler SPSS 23 yazılımı ile analiz edilmiştir. İkili grupların karşılaştırmalarında Kikare testi kullanılmıştır. Yaşlılarda düşme durumu ve ilişkili risk faktörlerinin belirlenmesi için yaş grupları ve cinsiyete göre dört farklı çoklu lojistik regresyon analizi yapılmıştır. Lojistik regresyon analizlerinde olası risk faktörü değişkenleri için referans gruplar "0" olarak kodlanmıştır. Araştırmaya katılım tamamen gönüllük esasına dayalı olup, çalışma için Hacettepe Üniversitesi bünyesindeki Girişimsel Olmayan Araştırmalar Etik Kurulu'ndan 21.05.2013 tarih ve GO 13/276-35 karar numaralı onay ile Sinop İ Halk Sağlığı Müdürlüğü'nden ve katılımcılardan yazılı izin alınmıştır.

\section{BULGULAR}

Araştırmada görüşülen yaşlıların bazı sosyodemografik özellikleri Tablo 2'de sunulmuştur. Katılımcıların \%28,3'ü yalnız yaşadıklarını belirtmiştir. Yaşılırın \%55,1'i yaşamları boyunca herhangi bir okuldan mezun olmadıklarını belirtmişlerdir. Katılımcıların \%43,9'u geçmişte gelir getiren bir işte

Tablo 1. Araştırmaya katılanların cinsiyet ve yaş gruplarına göre dağılımı (Sinop, 2013)

\begin{tabular}{|c|c|c|c|c|c|c|}
\hline \multirow{3}{*}{ Yaş grubu } & \multirow{2}{*}{\multicolumn{4}{|c|}{ Cinsiyet }} & \multicolumn{2}{|c|}{ Toplam } \\
\hline & & & & & & \\
\hline & $\mathrm{n}$ & $\%$ & $\mathbf{n}$ & $\%$ & $\mathrm{n}$ & $\%$ \\
\hline $65-74$ & 662 & 58,7 & 645 & 56,5 & 1307 & 57,6 \\
\hline 75 ve üstü & 465 & 41,3 & 497 & 43,5 & 962 & 42,4 \\
\hline Toplam & 1127 & 100,0 & 1142 & 100,0 & 2269 & 100,0 \\
\hline
\end{tabular}


Tablo 2. Araştırmaya katılanların cinsiyet ve yaş gruplarına göre dağılımı (Sinop, 2013)

\begin{tabular}{llll}
\hline \multicolumn{1}{c}{ Özellik } & & $\mathbf{n}$ & $\%$ \\
\hline Birisiyle birlikte yaşama durumu & Yalnız yaşıyor & 641 & 28,3 \\
& Yalnız değil & 1628 & 71,7 \\
Öğrenim durumu & Herhangi bir okuldan mezun olmuş & 1018 & 44,9 \\
& Hiçbir okuldan mezun olmamış & 1251 & 55,1 \\
Hayatı boyunca gelir getiren herhangi & Çalışmış & 997 & 43,9 \\
bir işte çalışmış olma durumu & Çalışmamış & 1272 & 56,1 \\
Halen gelir getiren bir işte & Çalışıyor & 154 & 6,8 \\
çalışıyor olma durumu & Çalışmıyor & 2115 & 93,2 \\
Toplam & & 2269 & 100,0 \\
\hline
\end{tabular}

çalışmışlardır ve \%6,8'i halen gelir getiren bir işte çalışmaktadır. Araştırmaya katılan tüm yaşılırın \%71,2'sinin en az bir kronik hastalığı bulunurken yine tüm yaşlıların \%62,1'i sürekli olarak her gün az bir ilaç kullandıklarını belirtmiştir. Sürekli olarak ilaç kullananların \%3,8'i günde 4 ya da daha fazla ilaç kullanmaktadır. Yaşlıların \%18'i ancak birisinden ya da bir araçtan destek alarak yürüyebilmektedir. GDÖ sonuçlarına göre yaşlıların \%45'inin depresyon riski olduğu saptanmıştır. LBI skorları açısından araştırma grubunda ölçeğe göre "bağımlı" durumda olan kimse bulunmamakta, yaşlıların \%24,4'ünün yarı bağımlı oldukları görülmektedir. Yaşlıların düşme konusundaki farkındalıklarının değerlendirildiği Fab ölçeği skoru ortalaması ve standart sapması $2,7 \pm 0,5$ olarak hesaplanmıştır. Araştırmaya katılan yaşılıarın \%36,4'ü 65 yaşından sonra en az bir kez düştüklerini belirtmiştir. Yaşlıların \%56,5'i düşmelerden korunma konusundaki bilgi düzeylerini yeterli bulurken \%31,6'sı düşme korkusu yaşadıklarını belirtmiştir. Katılımcılar bugünkü sağlık durumlarını "0" ile "100" arasında puanladıkları bir ölçek üzerinden belirtmişlerdir. Buna göre puan ortalamaları $56,1 \pm 19,3$ olarak hesaplanmıştır. Araştırmaya katılan yaşılıarın 65 yaşından sonra en az bir kez düşmüş olma durumları ile yaş grupları ve cinsiyetleri arasında istatistiksel

Tablo 3. 65 yaşından sonra düşme durumunun yaş grupları ve cinsiyete göre dağılımları

\begin{tabular}{llllll}
\hline & \multicolumn{2}{l}{ Düşmemiş } & \multicolumn{2}{l}{ Düşmüş } & p \\
& $\mathbf{n}$ & $\%$ & $\mathbf{n}$ & $\%$ & \\
\hline Yaş grubu & & & & & 0,367 \\
65-74 & 842 & 64,4 & 465 & 35,6 & \\
$75+$ & 602 & 62,6 & 360 & 37,4 & \\
Cinsiyet & & & & & 0,057 \\
Erkek & 739 & 65,6 & 388 & 34,4 & \\
Kadın & 705 & 61,7 & 437 & 38,3 & \\
Toplam & 1444 & 63,6 & 825 & 36,4 & \\
\hline
\end{tabular}

olarak anlamlı bir farklılık bulunmamıştır (Tablo 3). $\mathrm{Bu}$ nedenle düşme durumuna etki eden faktörleri belirlemek amacıyla 75 yaş altı erkekler, 75 yaş ve üstü erkekler, 75 yaş altı kadınlar ve 75 yaş ve üstü kadınlarda düşme durumuna etki edebilecek değişkenlerle ayrı ayrı lojistik regresyon analizleri yapılmıştır (Tablo 4).

Herhangi bir okuldan mezun olmamış olmak hem 75 yaş altındaki hem de 75 yaş ve üzeri yaşlılarda her iki cinsiyet için de düşme riskini 2-9 kat arttırdığı gösterilmiştir. Hayatı boyunca herhangi bir dönemde gelir getiren bir işte çalışmış olma ile halen çalışıyor olma durumunun düşme riskini artırdığı gösterilememiştir. Mevcut sağlık durumu puanı yükseldikçe her dört grupta da düşme riski istatistiksel olarak anlamlı şekilde azalmaktadır. Herhangi bir kronik hastalığa sahip olmak; 75 yaş altında düşme riskini artırmaktayken, sürekli olarak ilaç kullanıyor olmak her iki yaş grubunda da düşmeler için bir risk faktörü olarak bulunmuştur. Aynı şekilde günlük olarak kullanılan ilacın sayısı arttıkça düşme riski de her iki yaş grubu için de artış göstermektedir. Yalnız yaşamanın 75 yaş altındaki erkeklerde düşme riskini iki kat, 75 yaş ve üzeri kadınlarda 11 kat artırdığı bulunmuştur. Birisinden ya da bir gereçten destek almadan yürüyemeyen yaşlılarda düşme riski 3 ila 9 kat artmaktadır. Düşme korkusu yaşıyor olmak her iki yaş grubu ve cinsiyette düşme riskini 3-12 kat artırmaktadır. Düşmelerden korunma ile ilgili bilgi düzeyini yetersiz bulan 75 yaş altındaki kadınlarda ve 75 yaş ve üzeri erkeklerde düşme riski istatistiksel olarak anlamlı düzeyde artmaktadır (sırasıyla; $3,91(1,90 \pm 8,04)$ ve $7,80(3,10 \pm 19,61))$. Geriatrik Depresyon Ölçeği sonuçlarına göre depresyon riski olan yaşlılarda düşme riski her iki yaş grubunda da artış göstermektedir. Düşmeler konusundaki farkındalığı değerlendiren Fab skorunun yükselmesi her iki yaş grubundaki erkeklerde düşme riski 
Tablo 4. Araştırmaya katılan yaşlıların yaş grupları ve cinsiyetlerine göre düşme durumlarına etki eden risk faktörleri (Sinop, 2013)

\begin{tabular}{|c|c|c|c|c|}
\hline & $\begin{array}{l}75 \text { yaş altı erkek } \\
\text { OR }(\% 95 \mathrm{GA})\end{array}$ & $\begin{array}{l}75 \text { yaş altı kadın } \\
\text { OR }(\% 95 \mathrm{GA})\end{array}$ & $\begin{array}{l}75 \text { yaş üstü erkek } \\
\text { OR }(\% 95 \text { GA) }\end{array}$ & $\begin{array}{l}75 \text { yaş üstü kadın } \\
\text { OR }(\% 95 \text { GA) }\end{array}$ \\
\hline $\begin{array}{l}\text { Herhangi bir } \\
\text { okuldan mezun } \\
\text { olmamıs }\end{array}$ & $9,43(4,75 \pm 18,72)^{*}$ & $2,30(1,22 \pm 4,31)^{* *}$ & $4,42(1,97 \pm 9,94)^{*}$ & $2,94(1,38 \pm 6,24)^{* *}$ \\
\hline $\begin{array}{l}\text { Gelir getiren } \\
\text { bir işte hiç } \\
\text { calısmamıs }\end{array}$ & $0,96(0,58 \pm 1,59)$ & $3,73(1,74 \pm 8,00)^{*}$ & $1,82(0,89 \pm 3,72)$ & $0,46(0,04 \pm 4,92)$ \\
\hline $\begin{array}{l}\text { Halen gelir } \\
\text { getiren bir } \\
\text { işte çalışmıyor }\end{array}$ & $1,34(0,66 \pm 2,73)$ & $4,02(1,47 \pm 10,99)^{* *}$ & & $1,27(0,34 \pm 4,76)$ \\
\hline $\begin{array}{l}\text { Bugünkü sağlık } \\
\text { durumu algısı puanı }\end{array}$ & $0,98(0,96 \pm 0,99)^{*}$ & $0,96(0,94 \pm 0,98)^{*}$ & $0,98(0,96 \pm 0,99)^{* *}$ & $0,89(0,84 \pm 0,93)^{*}$ \\
\hline $\begin{array}{l}\text { Herhangi bir kronik } \\
\text { hastalığı var }\end{array}$ & $3,74(1,52 \pm 9,18)^{* *}$ & $11,73(3,54 \pm 38,88)^{*}$ & & $0,34(0,06 \pm 1,90)$ \\
\hline $\begin{array}{l}\text { Sürekli kullandığı } \\
\text { bir ilaç var }\end{array}$ & $2,69(1,22 \pm 5,90)^{*}$ & $40,07(10,81 \pm 148,49)^{* *}$ & & $8,53(1,58 \pm 46,08)^{*}$ \\
\hline $\begin{array}{l}\text { Günlük kullanılan } \\
\text { ilaç sayısı }\end{array}$ & $3,83(1,91 \pm 7,72)^{* *}$ & $3,03(1,92 \pm 4,77)^{* *}$ & $1,07(0,41 \pm 2,81)$ & $4,66(2,30 \pm 9,45)^{*}$ \\
\hline Yalnız yaşıyor & $2,49(1,37 \pm 4,55)^{* *}$ & $1,60(0,81 \pm 3,14)$ & $0,70(0,38 \pm 1,28)$ & $11,03(3,46 \pm 35,17)^{*}$ \\
\hline Destekli yürüyebiliyor & $4,23(2,39 \pm 7,51)^{*}$ & $3,65(1,61 \pm 8,25)^{* *}$ & $9,20(3,04 \pm 27,83)^{*}$ & $0,66(0,26 \pm 1,66)$ \\
\hline Düşme korkusu var & $8,97(5,00 \pm 16,01)^{*}$ & $3,03(1,49 \pm 6,15)^{* *}$ & $10,90(5,57 \pm 21,34)^{*}$ & $12,74(5,26 \pm 30,86)^{*}$ \\
\hline $\begin{array}{l}\text { Düşmelerden } \\
\text { korunma hakkında } \\
\text { bilgi düzeyi yetersiz }\end{array}$ & $1,19(0,70 \pm 2,02)$ & $3,91(1,90 \pm 8,04)^{*}$ & $7,80(3,10 \pm 19,61)^{*}$ & $0,40(0,06 \pm 2,53)$ \\
\hline $\begin{array}{l}\text { Geriatrik Depresyon } \\
\text { Ölçeği sonucu pozitif }\end{array}$ & $1,24(0,80 \pm 1,92)$ & $4,06(2,36 \pm 6,98)^{*}$ & $19,66(6,79 \pm 56,93)^{*}$ & $3,58(1,75 \pm 7,30)^{*}$ \\
\hline $\begin{array}{l}\text { Düşme konusunda" } \\
\text { farkındalık düzeyi } \\
\text { (Fab skoru) }\end{array}$ & $0,57(0,38 \pm 0,87)^{* *}$ & $0,79(0,38 \pm 1,68)$ & $0,04(0,01 \pm 0,17)^{*}$ & \\
\hline $\begin{array}{l}\text { Lawton Brody’ye } \\
\text { göre yarı bağımlı }\end{array}$ & $1,30(0,78 \pm 2,18)$ & $0,99(0,55 \pm 1,79)$ & $2,43(1,22 \pm 4,81)^{* *}$ & $33,70(8,16 \pm 139,25)^{*}$ \\
\hline Sabit & $-2,854$ & $-30,784$ & 0,471 & $-18,232$ \\
\hline
\end{tabular}

açısından koruyucu etki göstermektedir (sırasıyla $0,57(0,38 \pm 0,87)$ ve $0,04(0,01 \pm 0,17))$. Lawton ve Brody indeksi skoruna göre günlük yaşam aktivitelerinde başkalarına bağımlı olmak 75 yaş altında istatistiksel olarak anlamlı bir etki oluşturmazken 75 yaş ve üzeri grupta her iki cinsiyet için düşme riskini artırmaktadır

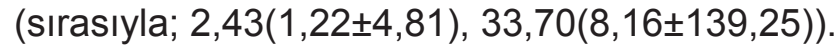

\section{TARTIŞMA}

Düşmeler, yaşlılık döneminde önemli bir halk sağlığı sorunudur. 65 yaş üzeri kişilerde düşmeler, en sık görülen kaza türüdür ve yaralanmalara bağlı hastanede yatışların en sık sebebidir. Yaşlılarda düşmelere bağlı yaralanmalar sıklıkla engellilik, bağımsızlığın kaybı ve artmış mortaliteyle sonuçlanmaktadır (29). Türkiye'deki yaşlı nüfusun en yoğun olduğu Sinop ilinde yapılan ve tüm 65 yaş üzeri nüfusu temsil eden bu kesitsel tipteki araştırmada 65 yaşından sonra düşme sıklığı \%36,4 olarak bulunmuştur. Yaşlılık döneminde düşmeler genellikle kadınlarda erkeklere göre daha yüksek sıklıkta görülmektedir (12). Ancak bizim çalışmamızda düşme sıklığı açısından cinsiyetler arasında istatistiksel olarak anlamlı bir fark bulunmamıştır. Bununla birlikte yapılan çok değişkenli analizler sonucunda yaşlılık döneminde çeşitli risk faktörlerinin erkeklerde ve kadınlarda ve 75 yaş altında ve 75 yaş ve üzerinde farklı derecelerde etkileri olduğu ortaya konulmuştur. Düşme risklerini değerlendirirken yaşlılık dönemi genellikle 65 yaş ve üzeri tüm bireyler şeklinde bir bütün olarak ele alınmaktadır. Bizim çalışmamızda yaşıılık dönemi; yaşlı (75 yaş altı) ve ileri yaşlı (75 yaş ve üzeri) olacak şekilde cinsiyetlere göre değerlendirilerek toplam dört grupta ele alınmıştır. 
$\mathrm{Bu}$ sayede düşme riskini artıran faktörlerin daha özelleşmiş gruplar için belirlenebilmesi ve bu sayede uygun ve sadece asıl risk altındaki grubu hedefleyen dar spektrumlu müdahalelerin geliştirilebilmesine olanak sağlanmaktadır.

Bazı sosyodemografik özelliklerin düşme riski ile ilişkisi bilinmektedir. Öğrenim durumu, yaşlılarda düşmeler ve düşmelere bağlı yaralanmalar açısından tanımlanmış önemli risk faktörlerinden birisidir (30). Bizim çalışmamızda da her iki yaş grubu ve cinsiyet için de düşme riski, herhangi bir okuldan mezun olmamış yaşılılarda 2,30 ile 9,43 kat arasında değişen sıklıklarda artış göstermektedir. Ancak literatürde daha önce gelir getiren bir işte çalışmış olmak ile halen gelir getiren bir işte çalışıyor olmanın yaşlılarda düşmeler ile ilişkisini tanımlayan bir çalışmaya rastlanmamıştır. İstihdam edilmiş olmak bireylerin nöroplastisitesini ve bilişsel durumunu olumlu yönde etkilemektedir (31). Bunun sonucunda da düşmelere karşı koruyucu etki gösterme olasılığı bulunmaktadır. Bizim çalışmamızda daha önce gelir getiren bir işte çalışmış olma ile düşmeler arasında istatistiksel olarak anlamlı bir ilişki saptanmamıştır. Sadece 75 yaş altındaki kadınlarda halen gelir getiren bir işte çalışıyor olmanın düşme riski açısından koruyucu etkisi olduğu ortaya çıkmıştır. Literatürde yaşlıların düşmeleri istihdam durumları arasındaki ilişkileri değerlendiren çalışmaların yokluğu, istatistiksel anlamlılık taşımayan makalelerin yayınlamıyor olmasından kaynaklanıyor olabilir (32). Yaşlılarda kronik hastalıkların varlığı, düşmeler için önde gelen risk faktörlerinden birisi olarak tanımlanmaktadır. Farklı kronik hastalıklar yaşlııkta düşme riskini farklı derecelerde artırırken, hastalığın ne olduğundan bağımsız olarak herhangi bir kronik hastalık varlığı ayrıca başı başına bir risk faktörüdür (33). Bizim çalışmamızda da 75 yaş altındaki yaşlılarda kronik hastalığın olması her iki cinsiyet için de düşme riskini artıran bir faktör olarak bulunmuştur. Kronik hastalık sahibi olmanın yaşılarda düşme riskini artırmasının yanı sıra genel sağlık durumu da benzer şekilde risk faktörü olarak bulunmuştur. Çalışmamızda yaşılıarın mevcut sağlık durumlarını kötüden iyiye doğru artan şekilde puanlamaları istenmiştir. Mevcut sağlık durumu algısı puanının artması her dört grupta da düşme riski açısından istatistiksel olarak anlamlı şekilde koruyucu etki göstermektedir. Benzer şekilde bireylerin iyilik halinin yükselmesinin düşmelere ve düşmeler sonucunda meydana gelen yaralanmalara karşı koruyucu olduğu literatürde gösterilmektedir (34).
Yaşılıarda kronik hastalıklara bağlı olarak düzenli olarak ilaç kullanıyor olmak düşme riskini artırmaktadır ve kullanılan ilaç sayısı artıkça düşme riski de artmaktadır (15). Bu çalışmada da 75 yaş ve üzeri erkekler dışında diğer gruplarda sürekli olarak ilaç kullanıyor olmanın düşme riskini artırdığı gösterilmiştir. Ayrıca kullanılan ilaç sayısı arttıkça bu gruplarda düşme riski istatistiksel olarak anlamlı şekilde artmaktadır. Yalnız yaşamak yaşılırda fonksiyonel yeterliliğin bir göstergesi olarak değerlendirilebilse de İngiltere Ulusal Araştırmasında yalnız yaşayan yaşlı bireylerin düşme riskinin, birisiyle beraber yaşayanlara göre 1,7 kat yüksek olduğu gösterilmiştir (35). Bizim çalışmamızda düşme riski 75 yaş ve altındaki erkeklerde 2,49 kat, 75 yaş ve üzerindeki kadınlarda 11,03 kat artmış olarak bulunmuştur.

Yürümeye destek olan yürüteç, baston gibi cihazlar yaşılıarın daha güvenli yürümesine yardımcı olmak için tasarlanmış olmakla birlikte, yürüme yetisini desteksiz olarak yerine getiremeyecek olan grup tarafından kullanıldıklarından yaşlılarda düşmelerle yakın ilişki göstermektedirler (36). Desteksiz olarak yürüyemeyen yaşlıların düşme riskleri bu araştırmada da 75 yaş ve üzeri kadınlar dışında 3,65 ile 9,20 kat arasında artmış olarak saptanmıştır. Düşmekten korkan, düşme korkusu nedeniyle anksiyete yaşayan yaşlılar hem bu korkuları nedeniyle fiziksel aktivitelerini kısıtlamakta, hem de daha yüksek sıklıkta düşmektedirler (37). Bu çalışmada da mevcut literatürle uyumlu olarak hem yaşılıarda hem de ileri yaşlılarda her iki cinsiyette de düşme korkusu bulunanlarda düşme riski 3 ila 12 kat artmıştır. Benzer şekilde düşmelerden korunma konusunda yeterli bilgiye sahip olmadığını belirten 75 yaş altındaki kadınlarda ve 75 yaş ve üzeri erkeklerde düşme riski istatistiksel olarak anlamlı şekilde yükselmektedir. Nedenselliği tam bilinmemekle birlikte geriatrik dönemde düşmeler, depresyonla birliktelik göstermektedir (14, 38). Bu çalışmada da Geriatrik Depresyon Ölçeğine göre depresyon yönünden pozitif kabul edilen yaşlılarda 75 yaş altındaki kadınlarda ve 75 yaş ve üzeri her iki cinsiyet için de düşme riski artmaktadır. Düşmeler hakkında farkındalığın artırılması, yaşlılarda düşmelerin önlenmesine yönelik en etkili müdahalelerden birisidir (9). Düşmeler hakkında farkındalık ve risk algısı arttıkça, düşme sıklığı anlamlı şekilde azalmaktadır (39). Bizim çalışmamızda da her iki yaş grubundaki erkeklerde Fab skoru ile ölçülen düşmeler hakkındaki farkındalığın artmasının, düşme riski açısından koruyu etki gösterdiği bulunmuştur, ancak araştırma grubundaki kadınlarda benzer bir ilişki saptanmamıştır. 
Farklı gruplarda benzer çalışmaların yapılması, olası ilişkilerin saptanması açısından faydalı olacaktır. Günlük yaşam aktivitelerini bağımsız olarak yerine getirebilme becerisi, yaşlıların yaşam kalitelerini artıran bir faktör olmakla birlikte, düşme sıklığının azalmasına da etki etmektedir. Günlük yaşam aktivitelerini bağımsız olarak yerine getirebilen yaşılarda düşme sıklığı, özellikle de tekrarlayan düşmelerin sıklığı azalmaktadır (40).

\section{SONUÇ}

Yaşlılarda düşmelerin önemi, sıklığı ve ilişkili risk faktörleri literatürde açıkça ortaya konulmuş durumdadır. Ancak yaşlılık döneminde bu kadar büyük mortalite ve morbidite yükü olan bu sağlık sorunu çoğunlukla 65 yaş üzeri bireylerde bir bütün olarak incelenmiştir. 65 yaş ve üzeri dönemin kendi içinde yaşlı (65-75 arası) ve ileri yaşlı (75 yaş ve üzeri) olarak ayrılması sonucunda ortaya çıkan gruplar ve bu gruplarda cinsiyetlere göre ayrım yaparak risk faktörlerinin belirlendiği çalışmalar çok az sayıdadır. Bizim çalışmamızda yaşılarda düşmelere ilişkin bilinen risk faktörlerinin yaşlılık içindeki yaş gruplarına ve cinsiyete göre farklılıkları değerlendirilmiş ve çarpıcı sonuçlara ulaşılmıştır. Herhangi bir okuldan mezun olmamış olmak, mevcut sağlık durumu algısının düşük olması ve düşme korkusu yaşıyor olmak tüm gruplarda düşmeler için bir risk faktörü olarak belirlenmiştir. Bununla beraber, daha önce gelir getiren bir işte çalışmamış olmak ve halen gelir getiren bir işte çalışmıyor olmak sadece 75 yaş altındaki kadınlar için risk faktörü olarak bulunmuştur. Bir başka önemli sonuç ise kronik hastalık sahibi olmanın düşme riskini 75 yaş altındaki grupta artırırken 75 yaş ve üzeri grupta bu etkisinin gözlenmemiş olmasıdır. Fab skoru ile değerlendirilen düşmeler konusundaki farkındalık düzeyi her iki yaş grubunda da sadece erkekler için koruyucu olarak bulunmuş ve kadınlar için istatistiksel olarak anlamlı bir fark saptanmamıştır. Lawton-Brody ölçeği sonuçlarına göre günlük yaşam aktivitelerini yerine getirmede başkalarına bağımlı olan yaşılarda 75 yaş ve üzerinde düşme riski artarken, 75 yaş altı grupta bu etki izlenmemiştir.

Sonuç olarak düşmeler yaşlılık dönemi için önemli bir halk sağlığı sorunudur ve düşmelerin önlenmesi ile risk faktörlerinin kontrolü konularında ileriye dönük müdahalelerin planlanmasında 65 yaş üzeri nüfus içerisinde yaş ve cinsiyet gibi belirleyicilere bağlı olarak risk faktörlerinin değişiklik gösterdiği göz önüne alınmalıdır.
Çıkar Çatışması: Çalışmada herhangi bir çıkar çatışması yoktur.

Finansal Çıkar Çatışması: Çalışmada herhangi bir finansal çıkar çatışması yoktur.

Yazışma Adresi: Tahsin Gökhan Telatar, Recep Tayyip Erdoğan Üniversitesi Tıp Fakültesi Halk Sağlığı Anabilim Dalı, Rize, Türkiye

Tel: + 05054671136

E-mail: posta: gokhantelatar@gmail.com

\section{KAYNAKLAR}

1. Türkiye İstatistik Kurumu İstatistiklerle yaşlılar. 2017: TUiK; 2018, March 15 [cited 2018 2018, June 14]. Available from: http://www.tuik.gov.tr/PreHaberBultenleri.do?id=27595.

2. World Health Organization. World Report on Ageing and Health World Health Organization, 2015.

3. Hickey A, Barker M, McGee H, et al. Measuring health-related quality of life in older patient populations. Pharmacoecon 2005;23(10):971-93.

4. Jiang HX, R MS, A DD, et al. Development and initial validation of a risk score for predicting in-hospital and 1-year mortality in patients with hip fractures. J. Bone Miner Res 2005;20(3):494-500.

5. Smartrisk. The economic burden of injury in Canada. Social Planning Council, Toronto, ON: 2009.

6. Günaydın R. Assessment of quality of life in older people. Turk Geriatri Derg 2010;13(4):278-84.

7. Rubenstein LZ, Josephson KR, Robbins AS. Falls in the nursing home. Ann Intern Med 1994;121(6):442-51.

8. Cumming RG, Salkeld G, Thomas M, et al. Prospective study of the impact of fear of falling on activities of daily living, SF36 scores, and nursing home admission. J Gerontol A Biol Sci Med Sci 2000;55(5):M299-305.

9. Clemson L, Cumming RG, Kendig $\mathrm{H}$, et al. The effectiveness of a community-based program for reducing the incidence of falls in the elderly: A randomized trial. J Am Geriatr Soc 2004;52(9):1487-94.

10. Thiem U, Klaaßen-Mielke R, Trampisch $U$, et al. Falls and $E Q-5 D$ rated quality of life in community-dwelling seniors with concurrent chronic diseases: a cross-sectional study. Health Qual Life Outcomes 2014;12(1):2.

11. Güner SG, Ural N. Yaşılıarda düşme: Ülkemizde yapılmış tez çalışmaları kapsamında durum saptama. İzmir Katip Çelebi Üniversitesi Sağlık Bilimleri Fakültesi Dergisi 2017;2(3):9-15.

12. Gale CR, Cooper C, Aihie Sayer A. Prevalence and risk factors for falls in older men and women: The English longitudinal study of ageing. Age Ageing 2016;45(6):789- 94 .

13. Campbell AJ, Reinken J, Allan B, et al. Falls in old age: a study of frequency and related clinical factors. Age Ageing 1981;10(4):264-70.

14. Tinetti ME, Speechley M, Ginter SF. Risk factors for falls among elderly persons living in the community. $\mathrm{N}$ Engl J Med 1988;319(26):1701-7.

15. Blake A, Morgan K, Bendall M, et al. Falls by elderly people at home: Prevalence and associated factors. Age Ageing 1988;17(6):365-72.

16. Downton J, Andrews K. Prevalence, characteristics and factors associated with falls among the elderly living at home. Aging Clin Exp Res 1991;3(3):219-28.

17. Stalenhoef $P$, Diederiks J, Knottnerus J, et al. A risk model 
for the prediction of recurrent falls in community-dwelling elderly: a prospective cohort study. J Clin Epidemiol 2002;55(11):1088-94.

18. Graf $\mathrm{C}$. The Lawton instrumental activities of daily living (IADL) scale. Medsurg Nurs 2009;18(5):315-6.

19. Diker J, Etiler N, Yıldız M, et al. Altmış beş yaş üzerindeki kişilerde bilişsel durumun günlük yaşam aktiviteleri, yaşam kalitesi ve demografik değişkenlerle ilişkisi: Bir alan çalışması. Anadolu Psikiyatri Derg 2001;2(2):79-86.

20. Şahbaz M, Tel H. Evde yaşayan 65 yaş ve üzeri bireylerin günlük yaşam aktivitelerindeki bağımlılık durumu ile ev kazaları arasındaki ilişkinin incelenmesi. Turk Geriatri Derg 2006;9(2):85-93.

21. Üner S, Telatar TG. Sinop İli Kentsel Alanda 65 yaş ve üzeri kişilerin yaşam kaliteleri ve günlük enstrümantal aktivite düzeyleri. Turk Geriatri Derg 2012;Special issue Turkish Geriatrics 2012 Congress:15.

22. Üner S, Çaman ÖK, Güzel S, et al. Bir birinci basamak sağlık kuruluşuna başvuran 65 yaş ve üzeri kişilerin yaşam kalitesinin fiziksel boyutu ve Günlük aktivite bağımsızlık düzeyinin incelenmesi. Turk Geriatri Derg 2012;Special issue Turkish Geriatrics 2012 Congress:15.

23. Yesavage JA, Brink TL, Rose TL, et al. Development and validation of a geriatric depression screening scale: a preliminary report. J Psychiatr Res 1982;17(1):37-49.

24. Ertan T, Eker E, Şar V. Geriatrik depresyon ölçeğinin Türk yaşlı nüfusunda geçerlilik ve güvenilirliği. Noro Psikiyatr Ars 1997;34(2):62-71.

25. Sağduyu A. Yaşlılar için depresyon ölçeği: Hamilton depresyon ölçeği ile karşılaştırmalı güvenilirlik ve geçerlilik çalışması. Türk Psikiyatri Derg 1997;8(1):3-8.

26. Clemson L, Cumming RG, Heard R. The development of an assessment to evaluate behavioral factors associated with falling. Am J Occup Ther 2003;57(4):380-8.

27. Uymaz PE, Nahcivan N. Yaşlılar için düşme davranışları ölçeği'nin geçerlik ve güvenirliği. FNJN 2013;21(1):22-32.

28. Clemson L, Cumming RG, Heard R. The falls behavioural (FaB) scale for the older person. Instruction manual Lidcombe, NSW: The University of Sydney 2003.

29. Gill TM, Murphy TE, Gahbauer EA, et al. Association of injurious falls with disability outcomes and nursing home admissions in community-living older persons. Am J Epidemiol 2013;178(3):418-25.
30. Li YH, Song GX, Yu Y, et al. Study on age and education level and their relationship with fall-related injuries in shanghai, china. Biomed Environ Sci 2013;26(2):79-86.

31. Vance DE, Bail J, Enah CC, et al. The impact of employment on cognition and cognitive reserve\&58; implications across diseases and aging. Nursing: Research and Reviews 2016;55(1):61-71.

32. Easterbrook PJ, Gopalan R, Berlin JA, et al. Publication bias in clinical research. Lancet 1991;337(8746):867-72.

33. Lawlor DA, Patel R, Ebrahim S. Association between falls in elderly women and chronic diseases and drug use: Cross sectional study. BMJ 2003;327(7417):712-7.

34. Peel NM, McClure RJ, Hendrikz JKJA. Health-protective behaviours and risk of fall-related hip fractures: A populationbased case-control study. Age Ageing 2006;35(5):491-7.

35. Wickham C, Cooper C, Margetts B, et al. Muscle strength, activity, housing and the risk of falls in elderly people. Age Ageing 1989 (1):47-51.

36. Kaye HS, Kang T, LaPlante MP. Mobility Device Use in the United States. Disability Statistics Report 14. Washington, DC: US Department of Education, National Institute on Disability and Rehabilitation Research, 2000.

37. Friedman SM, Munoz B, West SK, et al. Falls and fear of falling: which comes first? A longitudinal prediction model suggests strategies for primary and secondary prevention. J Am Geriatr Soc 2002;50(8):1329-35.

38. Biderman A, Cwikel J, Fried A, et al. Depression and falls among community dwelling elderly people: A search for common risk factors. J Epidemiol Commun H 2002;56(8):6316.

39. Gopaul K, Connelly DM. Fall risk beliefs and behaviors following a fall in community-dwelling older adults: A pilot study. Phys Occup Ther Geriatr 2012;30(1):53-72.

40. Campbell AJ, Robertson MC, Gardner MM, et al. Randomised controlled trial of a general practice programme of home based exercise to prevent falls in elderly women. BMJ 199725;315(7115):1065-9. 